\title{
Congenital Malaria in Neonate
}

\author{
MAHMUDA HASSAN ${ }^{1}$, MARIUM BEGUM ${ }^{2}$, A W SHAMSUR ROB ${ }^{2}$, ASHRUF UDDIN AHMED $^{3}$, \\ TASLIM UDDINAHMED ${ }^{3}$
}

\section{Introduction:}

Normally symptoms of congenital malaria appears between 10 to 30 days of neonatal life at the post partum period ${ }^{1}$. However the disese may appears in first day of life or after one month. Congenital Malaria is a rare event in endemic zone ${ }^{2}$ like Afganistan, India, Iraq, Bangladesh ${ }^{3}$ where maternal antibody against malaria protect the child'. But in rare occasion it may developed in endemic zone in new born babies. In this case fever is not subsided by antibiotic therapy and the child developed anaemia, fever and splenomegaly. Jaundice, hepatomegaly are the associated features of congenital malaria ${ }^{4-6}$. In Addin hospital, we managed a 20 days old new born baby with these features, who was later diagnosed as a case of congenital malaria. Due to rarity of presentation of congenital malaria in our setup, we are reporting this case.

\section{Case Report}

A 20 days male neonate of a non-consanguineous parent, hailing from Gazipur, a low malarial risk area, born at term by normal vaginal delivery at a local clinic. Antenatal and natal history was uneventful, on physical examination baby was normal after birth and sent back home with advise for normal newborn care. At the age of 20 days, baby was admitted at neonatal unit of Ad-din women's medical college hospital with the history of high fever $\left(105^{\circ} \mathrm{F}\right)$ which was continuous in nature for one day, and abdominal distension, without any feeding problem. On examination the baby was mildly pale, mildly icteric, huge splenomegaly about $6 \mathrm{~cm}$ at the long axis with mild hepatomegaly about $3 \mathrm{~cm}$ below the right costal margin. Admission weight was $3 \mathrm{~kg},\left(25^{\text {th }}\right.$ percentiles), OFC was $34.5 \mathrm{~cm}$ ( $50^{\text {th }}$ percentiles), length $50 \mathrm{~cm}\left(50^{\text {th }}\right.$ percentiles) and provisionally was

1. Associate Professor, Ad-din women's Medical College and Hospital, Dhaka. Division of neonatology.

2. Assistant Professor, Ad-din women's Medical College and Hospital, Dhaka. Division of neonatology.

3. Assistant Professor, Ad-din women's Medical College and Hospital, Dhaka. Department of pediatrics.

Correspondence: Dr. Mahmuda Hassan. E mail : mahmudahasn @yahoo.com diagnosed as septicemia. On admission baby's $\mathrm{Hb} \%$; was $11.8 \mathrm{gm} / \mathrm{dl}$, total count were $18,000 / \mathrm{cmm}$ and differential count were lymphocyte $66 \%$, polymorphs $22 \%$, eosinophil $4 \%$, monocyte $8 \%$, basophil $0 \%$, platelet count was $1,20,000 / \mathrm{cmm}$. Random blood sugar was $4.4 \mathrm{mmol} / \mathrm{L}$, Serum bilirubin was $9.2 \mathrm{mg} / \mathrm{dl}$, serum electrolytes and serum calcium were within normal limit. Peripheral blood film showed mature white cells with above distribution with thrombocytopenia. Blood culture showed no growth of bacteria. On admission baby was given parental antibiotics, antipyretic, was kept nothing per oral and an intravenous fluid $10 \%$ baby saline $150 \mathrm{ml} / \mathrm{kg} /$ day was started.

At the same time there was maternal history of fever, around $103^{\circ} \mathrm{F}$ to $104^{\circ} \mathrm{F}$ which was intermittent in nature, associated with chills and rigor, headache and body ache, also had same type of illness during $1^{\text {st }}$ and $3^{\text {rd }}$ trimester of this pregnancy, for which no investigation was done but treated with quinine sulphate 2 tablets 3 times daily for 5 days on both occasion with paracetamol and became afebrile. Primaquine was not prescribed due to its contraindication during pregnancy. As there was a maternal history of high grade intermittent fever during antenatal period and responded well with anti-malarial drug and had same type of illness during post partum period, for that reason, we send baby's blood for ICT malaria, blood film for malarial parasite, which showed malarial parasite of plasmodium vivax, ICT for malaria was positive. During postpartum period, mother was found positive ICT for malaria and plasmodium vivax in blood film. After getting investigation reports, we added anti-malarial drug for the baby, chloroquine, $10 \mathrm{mg}$ base $/ \mathrm{kg}$ at first then $5 \mathrm{mg}$ base $/ \mathrm{kg}$ after 6,24 and 48 hours of the first dose. Primaquine is not required for treatment as tissue phase (liver phase) is absent in congenital malaria. Anti-malarial drug, sulphadoxine $(500 \mathrm{mg})$, pyrimethamine $(25 \mathrm{mg}), 3$ tablets single dose was also given to the mother and referred to a medicine specialist for further evaluation and management. On $3^{\text {rd }}$ day after getting the report of blood culture we stopped the parental antibiotics and breast feeding was started, intravenous fluid was stopped as the baby was feeding well and 
also voiding well. Baby completed the full course of anti-malarial drug at hospital and the baby became afebrile on $2^{\text {nd }}$ day of anti-malarial drug. Baby was discharged on $5^{\text {th }}$ day with exclusive breastfeeding, folic acid, iron and multivitamin supplementation for 1 month and advised for follow up after 1 month or whenever there is any problem within 1 month. During follow up after 36 days, baby's general condition was good, feeding well, afebrile, but hepatosplenomegaly were still present but size was reduced, no other signs of illness was there, blood film showed no malarial parasite, body weight increased 435 grams.

\section{Discussion}

Congenital malaria is a rare disorder which is difficult to interpret as most of the clinical features are similar to other diseases e,g, congenital sepsis. This disease is rare with occurrence rate of $0.3 \%$ in immune mothers and $7.4 \%$ in non-immune mothers. ${ }^{7,8,9}$, In areas of high endemicity, it is common for pregnant women to be parasitemic and the rate of placental infection range from $16 \%$ to $34 \% .{ }^{10}$ Parasite may also appear in the cord blood at delivery, but it is very unusual for neonate to sustain parasitemia or suffer disease. ${ }^{11}$ Babies born to non -immune mothers are more likely to suffer disease. ${ }^{12}$ Congenital malaria is not uncommon in many parts of the world but rare in areas with high endemicity. ${ }^{7}$ Congenital malaria has been reported as sporadic cases in different parts of the world though declared malaria free by the WHO, like in Singapore, reported a case 2 months old young infant of a Pakistani ethnic origin ${ }^{13}$. Also a review from 1966-2005, 81 cases of congenital malaria reported in USA. Predominant infecting species was Plasmodium vivax $(81 \%)$ and most mothers were (96\%) immigrant. ${ }^{14}$

Malaria during pregnancy in malaria endemic area may account for $2-15 \%$ of maternal anemia, $5-14 \%$ of low birth weight newborn and $3-5 \%$ of newborn deaths. ${ }^{15}$ Effects on fetus are as follows, parasite hide in placenta, interfere with the transfer of oxygen and nutrients to the baby, and increasing the risk of spontaneous abortion, preterm birth, low birth weight baby, the single greatest risk factor for death during first month of life and still birth. Maternal transfusion of parasite into the fetal circulation occurs either during pregnancy or at the time of delivery, by direct penetration through the chorionic villi or through premature separation of placenta. Malarial infection of the placenta may be accompanied by intervillous infiltrates of mononuclear cells. Intervillous mononuclear inflammation (IVMI) is specially severe in first trimester and it is associated with anemia and low birth weight. IVMI induces an alteration in the cytokine balance and may cause pathological changes in trophoblasts that can damage syncyto-trophoblastic membrane, subsequently leading to all fetal problems. ${ }^{16,17}$

Congenital malaria most commonly presents in 8 weeks of life with fever, vomiting, anemia, hepatomegaly, jaundice and mild diarrhea. ${ }^{12,18,19}$ Major diagnostic criteria is to find $P$ vivax in blood smears in thick and thin films. ${ }^{20}$ that we did and also ICT for malaria. The newborn was successfully treated with chloroquine for plasmodium vivax. Primaquine is not required for treatment as tissue phase (liver phase) is absent in congenital malaria. ${ }^{21}$ As mentioned earlier, his mother had two episodes of high grade intermittent fever, treated with quinine sulphate for 5 days, but not with primaquine as it is contraindicated during pregnancy 22,23 because it may cross the placenta and may cause hemolytic anemia in utero in D6PD- deficient fetuses. During postnatal period mother developed intermittent fever, associated with chill, rigor, head ache and body ache due to relapse of malaria confirmed by investigations, mother was treated with Anti-malarial drug sulphadoxine (500mg), pyrimethamine $(25 \mathrm{mg}), 3$ tablets single dose and referred to a medicine specialist for further evaluation and management. During follow up, the baby was found free from parasite in thick film, and was thriving well.

\section{Conclusion}

This case highlights the fact that even in endemic regions malaria can affect the neonate with its various presentation. In this case our working diagnosis was septicaemia, intrauterine infection and hematological malignancy. High index of suspicion, details history taking specially ante-natal history is very important to diagnose malaria in neonate and early infancy in a malaria endemic areas. Prompt treatment should be initiated to avoid malaria associated morbidity and mortality in a neonate.

\section{References}

1. Procop GW, Persing DH. Congenital Malaria. In: Wilson WR, Sande MA. Current diagnosis and Treatment in Infectious diseases. $1^{\text {st }}$ ed. McGraw-Hill 2001;798.

2. Krause PJ. Malaria. (Plasmodium). In: Keligman RM, Behrman RE, Jenson HB, Stanton BF 
editors. Nelson Text book of Pediatrics. $18^{\text {th }}$ ed. Philadelphia. Saunders company 2008; 1479.

3. Bartlet JG. Pocket Book of Infectious Diseases Therapy. $11^{\text {th }}$ ed. Philadelphia: Lippincot Williams \& Wilkins 2001;148.

4. Subramanian D, Moise KJ, White AC. Imported malaria in pregnancy: Report of four cases and review of management. Clinical Infectious disease 1992; 15: 408.

5. Arvin MM, Maldonado YA. Protozoan and Helminthes Infections. JS Remington, JO Klein. Editors. Infectious Diseases of the fetus and Newborn infant. $4^{\text {th }}$ ed. Philadelphia: WB Saunders 1995; 765-8.

6. Ibhaneschor SE. Clinical characteristics of neonatal malaria. J Trop Pediatr 1995; 41: 330-3.

7. Covell G. Congenital Malaria. Trop Disease Bulletin 1950; 1147-67.

8. Akindele J A, Sowunmi A, Abohweyere A E. Congenital Malaria in a hyper endemic area: a preliminary study. Ann Trop Paediatr 1993; 13:273-6.

9. Megregor I A. Epidemiology, malaria and pregnancy. Am J Trop Med Hyg 1984; 33:517525.

10. Jeliffe EFP. Low birth weight and infection of the placenta. Bull World Health Organization 1968; 38:69-78.

11. Strickland GT. Ed. Hunter's tropical medicine. $7^{\text {th }}$ ed. Philadelphia: WB Saunders 1991; 586-615.

12. Molyneux ME. Malaria -clinical features in children. J R Soc Med 1989; 82: 17-35.

13. W W R Lee, M Singh, C L Tan. A Recent Case of Congenital Malaria in Singapore. Singapore Medical Journal 1996;37:541-543.
14. Catherine R, Arguin, Robert D. Neuman. Congenital malaria in United States. A Review of cases from 1966 to 2005. Archives of Paediatrics and Adolescent Medicine 2007; 161(11): 1062-1067.

15. Desai M, O ter Kuile F, Nosten F, McGready R, Asamoa K, Brabin B, Newman R. Epidemiology and burden of malaria in pregnancy. Lancet Infect Dis. 2007 ; 7: 93-104

16. Okoko BJ, Enwere G, Ota MO.The epidemiology and consequences of maternal malaria: A review article immunological basis. Acta Trop 2003; 87(2): 197-205.

17. Crocker IP, Tenner OM, Myers JE. Syncytiotrophoblast degradation and the pathophysiology of the malaria infected placenta. Placenta 2004; 25(4):273-282.

18. Quinn TC, Jacobs RF, Mertz GJ. A report of 4 cases and a review. J Paed 1982; 8: 229-232.

19. Hulbert TV. Congenital malaria in United States, report of a case and review. Clin Infect Disease 1992;14:229-232.

20. Horbes BA. Bailey and Scott Diagnostic Microbiology. $11^{\text {th }}$ ed, St. Louis: Mosby 2002; 640-642.

21. Geddes AM, Bryceson ADM, Thin RN, Mitchell DM. Diseases due to infection. Edwards CRW, Bouchier ID, Haslett C, Chilvers E editors, Davidson's Principles and Practice of Medicine. $17^{\text {th }}$ edition. Churchill Livingstone 1995 ; 148-152.

22. Gills MC. Pramaquine, CPS compendium of pharmaceuticals and specialties. Ottawa, Canadian Pharmacist association. $3^{\text {rd }}$ edition 1998; 1355.

23. White NJ, Breman JG. Malaria and Babesiosis. Isselbacher KJ, Braunwald E, Wilson JD, Martin JB., Fauci AS, Kasper DL editors, Harrison's Principles of Internal Medicine. New York: McGraw Hill $17^{\text {th }}$ edition 2008;1:1293. 